\title{
Teachers' Efficacy for Supporting At-Risk Students and Their Perceived Role in Dropout Prevention
}

\author{
Kimberly Knesting-Lund, Ph.D. \\ University of Wisconsin-Whitewater \\ Brent O'Rourke, Ed.S. \\ Grant Wood Area Education Agency \\ Anthony Gabriele, Ph.D. \\ University of Northern Iowa
}

Received: April 4, 2015 Accepted: May 10, 2015 Published: May 10, 2015

doi:10.5296/jse.v5i2.7523 URL: http://dx.doi.org/10.5296/jse.v5i2.7523

\begin{abstract}
Research on the construct of teacher efficacy has demonstrated its positive relationship to a number of student outcomes, such as improved academic achievement, increased levels of self-efficacy, and a stronger belief in their ability to solve a math task and their motivation for completing it. Based on these findings, this research considered the possibility that teacher efficacy for supporting at-risk students could be related to their understanding of high school dropout, potentially suggesting ways to improve schools' dropout prevention efforts. This study was an initial exploration of the relationship between high school teachers' perceived efficacy for supporting at-risk students and their perceptions of their roles in the prevention of school dropout. Participants were 159 teachers from 4 Midwestern high schools, two in suburban areas and two in rural areas. Participants included both special and general education teachers from all content areas. Results suggest that teachers with higher self-efficacy for supporting at-risk students are more likely to identify causes of dropout within a school's control and more supportive of schools' role in dropout prevention.
\end{abstract}

Keywords: Dropout, Prevention, Teachers, At-risk students 
Research on high school dropout has begun to examine school and teacher influences on students' educational decisions. Increasingly, support has been found for the critical role of teachers in supporting students' persistence to graduation (Dunn, Chambers, \& Rabren, 2004). This suggests the importance of teachers believing in their effectiveness at helping their students persist in school, no matter what obstacles the students may be facing. However, some teachers may not see the positive influence they may have due to factors such as a belief that students' concerns are out of teachers' control (Knesting-Lund, Reese, \& Boody, 2013). Yet, if teachers who work with at-risk students on a daily basis do not realize the importance of their interactions with students and the positive effect they can have on student educational outcomes, schools' prevention efforts may be less effective. There is limited research on variables that may influence teachers' perceptions of their role in high school dropout prevention, specifically the construct of teacher efficacy.

There is a plethora of research on the construct of teacher efficacy and its relationship with multiple variables, such as teaching experience (Hoy \& Woolfolk, 1990), positive teacher outcomes (Allinder, 1994; Ashton \& Webb, 1986; Guskey, 1988; Ross, 1992), and positive student outcomes (Anderson, Greene, \& Loewen, 1988; Ashton \& Webb, 1986; Midgley, Feldlaufer, \& Eccles, 1989). Research on teacher efficacy and its relationship with high school dropout may increase understanding of dropout prevention programs and also suggest ways to improve schools' dropout prevention efforts. This study was an initial exploration of the relationship between high school teachers' perceived efficacy for supporting at-risk studentsand their perceptions of their roles in the prevention of school dropout.

\section{Dropout Prevention and Intervention Programs}

As school dropout rates remain unacceptably high (Mac Iver, 2011), and there is more widespread acknowledgment of the role schools can play in both students' decisions to leave early and to persist until graduation (Lehr, Hansen, Sinclair, \& Christenson, 20003), pressure is increasing for educators and policymakers to develop more effective prevention and intervention programs (Mac Iver, 2011). Yet, an understanding of the factors that may contribute to effective prevention and intervention strategies is strikingly limited (Barry \& Reschly, 2012). Based on their review of the dropout literature, Lehr et al. (2003) concluded that first, there were too few published studies on dropout prevention and intervention, and second, the research that was published was of limited quality. In addition, Lehr et al. (2003) highlighted the need for researchers, policy makers, and educators to shift their focus from merely helping at-risk students get through school with a diploma in hand to supporting students' learning throughout their school completion.

The challenge of implementing an effective dropout prevention program is illustrated in Mac Iver's (2011) 5-year longitudinal randomized study of a prevention program implemented at an urban high school, along with its comparison to a matched control school. The implemented prevention program was based on research reviewed by the Institute for Education Sciences (IES) What Works Clearinghouse (WWC; U.S. Department of Education, 2009) and focused on a specific recommendation from the IES developed practice guide for dropout prevention (IES, 2008), connecting at-risk youth with adult advocates. Data were 
collected from a group of students at both the prevention program and control high schools during the students' $9^{\text {th }}$ through $12^{\text {th }}$ grade years, as well as the year following their expected graduation. At the end of the five years, data analysis suggested that the students who participated in the prevention program were more likely to graduate than those students not in the program, but not at a level of statistical significance. In addition, logistic regression analysis indicated that the prevention program students' eighth-grade attendance record and eighth-grade GPA were significant predictors of future high school completion but participation in the prevention program was not.

Mac Iver (2011) postulates that one probable reason for the prevention program's lack of success was that implementation began too late in the students' school career, in $9^{\text {th }}$ grade instead of $8^{\text {th }}$ grade. Her analysis of the data suggested that by the time they were in $8^{\text {th }}$ grade students' attendance or truancy patterns were already well established and they did not change upon starting $9^{\text {th }}$ grade. In addition, she hypothesized that students' ability to handle high school level classwork also was strongly influenced by their middle school learning experiences. A second probable reason for the prevention program's limited success, according to Mac Iver (2011), was because it did not include school level factors such as school climate, instructional quality, opportunities for skill remediation, etc. in the services provided. If this is true, other research would suggest that an important key to the successful implementation of school level factors are positive student-teacher relationships and that teachers are not fully aware of the influence they can have on students' success (Davis \& Dupper, 2004).

\section{Student Perspectives on Dropping Out}

There are many different theories for why students drop out prior to graduation, yet the students themselves are often left out of the conversation about these reasons. Kortering and Braziel (1999) interviewed students with learning disabilities who had dropped out of school, asking questions such as whether or not they would return to school, and if there were things that could have been changed that would have kept them in school. Of the 44 individuals who were a part of the study, 64\% said that despite dropping out, they would consider going back to school. In discussing what would need to happen for them to experience more success at school if they were to return, the majority of the participants identified something related to their own behavior, such as changing their attitude towards school or improving their work habits. At the same time, the majority of participants also made specific suggestions regarding teacher and administrator factors. The primary theme of these responses addressed teachers changing their own attitudes towards students: "Not having an attitude problem," "Teachers need to calm down, we are not kids anymore," "Stop putting students into classes of rich and poor," and "Teachers think they are better than the student," are representative of the students' comments (Kortering \& Braziel, 1999, p. 81).

Using qualitative methods, Gallagher (2002) conducted multiple, in-depth interviews with four recent high school dropouts about their school experiences and their decisions to leave school. As with the dropouts who participated in Kortering and Braziel's (1999) research, these young people described how their own behavior impeded their successful 
school completion, primarily not placing a high enough priority on school and not putting forth enough effort. Yet, they also discussed the influence of teachers who made it more difficult for them to attend school, as well as how they valued the support they received from other teachers who they perceived as wanting to help them reach graduation. The following participant's reflection captures well a student's perspective of the important role that a teacher can have:

In sixth grade I had this one teacher who tried so hard, he was a good person, he was always really nice. Because that was when I started having problems, and I wasn't into school like I should have been. Like if I didn't do my homework, he'd sit me down with me and try, you know, he'd go over there and help me with it. He never lost his cool, he kept with me...And then he actually allowed me to teach other students... It really helped, and my grades went up and because of him I was able to make it through that year. (Gallagher, 2002, pp. 46-47)

Other qualitative studies whose participants were either students at-risk for dropping out (Knesting \& Waldron, 2006) or who had dropped out (Altenbaugh, Engel, \& Martin, 1995; Fine, 1991) also highlight the critical role teachers can play in helping students persist in school. Further, these studies suggest that dropout prevention programs should consider the influence of teacher characteristics in the evaluation of program effectiveness.

There can be a tendency to discount students' descriptions of how teachers contributed to their decisions to drop out of school as "sour grapes" or an unwillingness to accept responsibility for their own behavior, even though the students in these studies also identified how their own behavior interfered with their potential success (Gallagher, 2002; Kortering \& Braziel, 1999). Through her own observations of student and faculty interactions, Fine's (1991) critical ethnographic case study of an urban high school provides an outsider's support for students' contentions. At the beginning of her book, Framing Dropouts: Notes on the Politics of an Urban Public High School, Fine (1991) explained the purpose of her research as being "to unearth the policies and practices by which this typical comprehensive public high school could produce dropout rates estimated to be from 40 to 60 percent" (p. 2). She began the research focusing on students' decisions to drop out, until her observations led her to refocus to the school itself. Her field notes document example after example of school staff encouraging students to drop out rather than stay in. Her observations and interviews describe students who were told they were too old to stay in school, students expelled for frequent absenteeism, and students in classrooms where the only right answer was the one that the teacher wanted to hear. One of Fine's conclusions was that the beliefs and actions of the school's staff were largely responsible for the number of students who left school before graduation.

\section{Teacher Efficacy}

According to Shidler (2009), teacher efficacy is "a teachers' ability to see him/herself as capable of providing instruction within a content area and for the instruction provided to impact on student achievement" (p. 453). The concept grew out of Bandura's (1993) social cognitive theory, more specifically the construct of self-efficacy and its influence on human behavior (Klassen, Tze, Betts, \& Gordon, 2011). While the initial direction of researchers 
interested in Bandura's (1993) work was on the impact of students' self-efficacy on their own learning, increasingly, attention has focused on the impact of teachers' self-efficacy on student learning.Higher levels of teacher efficacy are associated with students' increased academic achievement (Ross, 1992), higher levels of their own self-efficacy (Anderson, Greene, \& Loewen, 1988), and a stronger belief in their ability to solve a math task and their motivation for completing it (Midgley, Feldlaufer, \& Eccles, 1989).

In the pilot phase of a classic study designed to validate the construct of teacher efficacy, Gibson and Dembo (1984) collected structured, observational data on a subsample of eight teachers who were identified as either low efficacy $(n=4)$ or high efficacy $(n=4)$ by the measure they were validating. Their purpose was to assess whether differing scores on the efficacy measure were associated with differences in classroom teaching behavior. The observation tool focused on multiple aspects of teachers' use of academic time as well as their praise for correct answers, criticism for incorrect answers, and the amount of persistence given to interactions with students who answered incorrectly. Important to the purpose of the current research, Gibson and Dembo (1984) found that low efficacy teachers were more likely to respond to incorrect answers with criticism, less likely to respond to correct answers with praise, and less likely to persist in helping a student who did not initially know the answer to a question. While these findings from Gibson and Dembo (1984) were from a small number of teachers and are tentative in nature, they do provide support for the possibility that teacher efficacy may influence teacher behavior with at-risk students.

Higher levels of teacher self-efficacy are associated with multiple positive outcomes for their students. Woolfolk, Rosoff, \& Hoy, (1990) found that teachers with higher levels of teacher efficacy were better able to motivate students and manage classroom behavior than teachers with lower levels of efficacy. Teachers who reported lower efficacy levels were more likely to avoid activities they thought would be too hard for them or that they believed werebeyond their capabilities. Additionally, lower efficacy teachers were less likely to persist with students experiencing learning difficulties in the classroom. In contrast, teachers who reported higher efficacy levels were more likely to continue to work with students until they experienced success. Cantrell, Almasi, Carter, and Rintamaa's (2013) study looking at teacher efficacy and student outcomes following the implementation of a supplemental reading intervention found that students working with higher efficacy teachers demonstrated more improved reading comprehension, vocabulary skills, and overall reading achievement as compared to students working with lower efficacy teachers. Based on their findings, Cantrell et al. (2013) suggest that teacher characteristics, including teacher efficacy, are as important to students' success in an academic intervention as the particular curriculum or program that is implemented to support learning.

As the struggle continues to develop effective dropout prevention and intervention programs, the critical influence of factors such as school belonging, academic engagement, and instructional quality cannot be ignored. At the same time, the influence that adults themselves have on at-risk students at school (and not just the nuts-and-bolts of the prevention and intervention programs being implemented), needs to be both acknowledged and valued (Ehrenreich, Reeves, Corley, \& Orpinas, 2012). Teachers' beliefs about their ability to 
successfully support students could influence their interactions with those students at-risk for dropping out of school.Because of the importance of teacher efficacy and its potential influence on teachers' effectiveness with implementing dropout prevention and intervention strategies, this pilot study sought to answer the following question: How are levels of teacher self-efficacy for student support correlated with their perceived role in dropout prevention?

\section{Methods}

\section{Participants}

Participants in this study were 159 teachers from 4 Midwestern high schools. Two of the schools were in suburban areas, while the other twowere located in rural areas.Participantsincluded both special and general education teachers from all content areas. The researchersreceived permission from the participating school district to conduct the research and teacher consent wasobtained before the measures were completed. The measures were administered by the second author during teacher in-service days at each of the high schools. The measures were distributed in a research packet that contained a cover letter providing an overview of the research and assuring anonymity of responses, describing the two measures, and with directions for completing the measures. The second author collected completed measures at the same in-service training at which they were distributed. One-hundred percent of the teachers invited to participate returned completed measures.

\section{Measures}

Two measures were used to gather data on teachers' perceived role in dropout prevention and their sense of efficacy for supporting students to graduation. First, a survey developed by Knesting-Lund et al. (2013) was used to look at teachers' perceived role in high school dropout prevention. On this measure, participants answered five demographic questions (school, content area taught, grade level taught, years of teaching experience, gender) and four items looking at different variables related to school dropout. The first of these items asked participants to identify on a 5-point scale (not a problem/mild problem/moderate problem/significant problem/do not know) how significant a problem they believed dropout was at the high school where they taught. The second item asked participants to describe on a 4-point scale (decreasing/staying the same/increasing/do not know) their school's dropout rate during the last five years. The third item required participants to describe on a 5-point scale (not at all/a little/some/significant/do not know) the personal influence they believed teachers could have on students' decisions to either stay in or drop out of school. The fourth item asked participants to rate on a 5-point scale (not important/mildly important/moderately important/very important/do not know) the importance of schools reducing the number of students who drop out. Finally, the participants described on a 4-point scale (not at all/some/significantly/do not know) the extent to which they believed 20 factors to contribute to high school dropout.

When asked to identify the contribution of 18 specific factors (some within a school's control such as frequently getting in trouble at school and others outside a school's control such as parenting a child) to students' decision to either persist in school or drop out, the teachers in 
Knesting-Lund et al.'s (2013) study were more likely to identify factors outside of their control. The factors teachers reported believing to have the most significant influence on students' decision to drop out of school were frequent absences, frequent trouble at school, limited parental support, low academic achievement, and being in trouble with the law. Additionally, the teachers described themselves as having a moderate influence on students' decision to stay in or drop out of school and as having a moderately important role in their schools dropout prevention efforts.

The second measure was an adaptation of Tschannen-Moran and Woolfok-Hoy's (2001) Teachers' Sense of Efficacy Scale. The Teacher Efficacy for Student Support Scale is a seven item measure that assesses teachers' efficacy for supporting students they consider to be at risk for dropping out of school. Responses are recorded on a 9-point scale, with total scores on the measure ranging from 7-63. The items ask about the influence of teachers' positive expectations on student persistence, unalterable variables on student outcomes, and socioeconomic status on students' academic success, as well as about teachers' ability to communicate effectively with students, motivate at-risk students, and teach at-risk students. Cronbach's alpha was used to compute the internal consistency reliability estimates for the items on the Teacher Efficacy for Student Support Scale with a resulting alpha coefficient of 0.79. Alpha coefficients greater than .7 are considered to have acceptable reliability for research purposes (Schmitt, 1996).

\section{Results}

Data were analyzed to identify correlations between participating teachers' sense of efficacy for supporting students at-risk for dropping out and their perceived role in dropout prevention. This group of teachers described their levels of self-efficacy for supporting students as being quite strong $(\mathrm{M}=46.69, \mathrm{SD}=8.02, \mathrm{n}=159)$. As shown in Table 1 , there were a number of statistically significant correlations between teachers' total score on the efficacy scale and the extent to which they perceived 20 factors as contributing to high school dropout. Weak positive correlations were found between self-efficacy for supporting students and the factors of teacher gender $(\mathrm{r}=.205, \mathrm{p}<.05)$, not having a close relationship with a teacher $(\mathrm{r}=.213$, $\mathrm{p}<.01)$, not having a sense of belonging at school $(\mathrm{r}=.195, \mathrm{p}<.05)$, feeling physically unsafe at school $(\mathrm{r}=.219, \mathrm{p}<.01)$, believing no one at school cares if students drop out $(\mathrm{r}=.310$, $\mathrm{p}<.01)$, believing adults at school want them to drop out $(\mathrm{r}=.186, \mathrm{p}<.05)$, school climate $(\mathrm{r}$ $=.310, \mathrm{p}<.01)$, and prevention programming $(\mathrm{r}=.167, \mathrm{p}<.05)$. 
Table 1. Correlations between Teacher Efficacy for Student Support and Factors Perceived as Contributing to School Dropout

\begin{tabular}{lc} 
Years teaching & .023 \\
Gender & $.205^{*}$ \\
Type of school (rural or urban) & .105 \\
Low academic achievement & -.077 \\
Working up to 15 hours per week & .028 \\
Working more than 15 hours per week & -.075 \\
Being retained or held back in school & -.042 \\
Frequently getting into trouble in school & .074 \\
Getting into trouble with the law & .031 \\
Frequent absences from school & .092 \\
Parenting a child & -.024 \\
Not having friends at school & .073 \\
Not having a close relationship with a teacher & $.213^{* *}$ \\
Not having a sense of belonging at school & .195 \\
Not seeing a benefit to earning a diploma & .107 \\
Being lazy and unmotivated & $.310^{* *}$ \\
Limited parental support for education &. .003 \\
Feeling physically unsafe at school & .029 \\
Feeling emotionally unsafe at school & $.219^{* *}$ \\
Believing no one at school cares if they drop out & $.310^{* *}$ \\
Believing adults at school want them to drop out & $.186^{*}$ \\
School climate & .150 \\
Prevention programming & \\
\hline
\end{tabular}

Note: $* \mathrm{p}<.05 .{ }^{* *} \mathrm{p}<.01$.

\section{Discussion}

Developing effective high school dropout prevention programs requires more than addressing characteristics inherent to at-risk students, but also addressing critical factors such as the 
school environment and teachers' willingness and ability to support students' persistence. As schools begin to implement dropout prevention programs that seek to reengage at-risk students through school supports and improved academic achievement, attention must be given not only to programs themselves but also those adults who are actively engaged with the programs (Knesting, 2008). As more recognition is given to the important influence that teachers can have on students' decisions to stay in school until graduation or drop out prior to receiving a diploma (Dunn et al., 2004), understanding teachers' perceptions of their role in dropout prevention, as well as their beliefs about their ability to support at-risk students, is increasingly important.

On the Teacher Efficacy for Student Support Scale, teachers in this study rated themselves as having moderate levels of self-efficacy. The teachers reported that they had the ability to improve academic outcomes for students from low socioeconomic status backgrounds, communicate with students they believed to be at-risk for dropping out, motivate at-risk students to do their best in school, and effectively teach at-risk students. Specifically, those teachers describing higher levels of efficacy for student support were more likely to describe the following factors as contributing to students' dropping out: 1) not having close relationships with teachers, 2) not having a sense of belonging, 3) feeling physically unsafe, 4) believing no one cares if students drop out, and 5) believing adults want them to drop out. Teachers choosing these items seemed to recognize the importance of students' sense of physical and psychological safety to their decisions to stay in or drop out of school. This supports the potential importance of attending to the personnel involved in dropout prevention programs, as well as the programs themselves.

Based on the results of her qualitative case study of a group of high school students at-risk for dropping out of school, Knesting (2008) discussed the importance of committed and caring teachers to supporting educational persistence in at-risk students. The students who participated in this case study stressed the importance of having positive communications with teachers who had high, yet achievable, goals for them. These teachers made time to provide additional instruction and academic support, expected them to follow school rules and be respectful of each other, and asked about students' life outside of school if they seemed to be struggling in school. These were the teachers the students described as caring about them, and these were the teachers to whom they turned when they were thinking about dropping out. The students' most significant complaints were with teachers who they perceived as not seeming to care about their success in school. These were teachers who did not ask about homework that was not turned in, did not offer additional support when the student said he or she was struggling with class content, or who did not talk with the student following an extended absence. This group of students interpreted these teacher behaviors to mean that the teachers' did not expect them to succeed; they did not care if they succeeded or not. In the current study, those items on the efficacy scale that were correlated with higher levels of teacher self-efficacy were the ones that the student participants in Knesting's (2008) study identified as meaning a teacher cared about them.

The more these participating teachers reported believing that factors such as having a sense of belonging at school, feeling physically safe while at school, and feeling as if people at school 
care contribute to students' decisions to stay in or drop out of school, the higher their levels of efficacy for dropout prevention were. This is important because teachers who perceive themselves as having high personal efficacy place a greater emphasis on factors external to a student to explain why or why not a student is successful. Additionally, they are more likely to assume direct responsibility for student failures than teachers with lower levels of efficacy. Higher efficacy teachers attribute student success more to the influence of a school-based program and less to influences from home (Hall, Hines, Bacon, \& Koulianos, 1992). The results of this pilot study indicate the need for additional research into how teacher characteristics may influence efficacy of dropout programs with which they are involved.

\section{References}

Allinder, R. M. (1994). The relationship between efficacy andthe instructional practices of special education teachers and consultants. Teacher Education and Special Education, 17, 86-95.http://dx.doi.org/10.1177/088840649401700203

Altenbaugh, R.J., Engel, D.E., \& Martin, D.T. (1995). Caring for kids: A critical study of urban school leavers. London: Falmer Press.

Anderson, R., Greene, M., \& Loewen, P. (1988). Relationships among teachers' and students' thinking skills, sense of efficacy, and student achievement. Alberta Journal of Educational Research, 34(2), 148-165.

Ashton, P. T., \& Webb, R. B. (1986). Making a difference: Teachers' sense of efficacy and student achievement. NewYork: Longman.

Bandura, A. (1993). Perceived self-efficacy in cognitive development and functioning. Educational Psychologist, 28(2), 117-148.http://dx.doi.org/10.1207/s15326985ep2802_3

Barry, M., \& Reschly, A. L. (2012). Longitudinal predictors of high school completion. School Psychology Quarterly, 27(2), 74-84. http://dx.doi.org/10.1037/a0029189

Davis, K. S., \& Dupper, D. R. (2004). Student-teacher relationships: An overlooked factor in school dropout. Journal of Human Behavior in the Social Environment, 9, 179-193.http://dx.doi.org/10.1300/J137v09n01_12

Dunn, C., Chambers, D., \& Rabren, K. (2004). Variables affecting students' decisions to drop out of school. Remedial and Special Education, 25, 314-323.http://dx.doi.org/10.1177/07419325040250050501

Ehrenreich, H., Reeves, P. M., Corley, S., \& Orpinas, P. (2012). With graduation in sight: Perceptions of high- and low-aggression students of the journey to high school completion. School Psychology Quarterly, 27(4), 198-209.http://dx.doi.org/10.1037/spq0000006

Fine, M. (1991). Framing dropouts: Notes on the politics of an urban public high school. Albany: State University of New York.

Gallagher, C.J. (2002). Stories from the strays: What dropouts can teach us about school. American Secondary Education, 30(3), 36-60. 
Gibson, S., \& Dembo, M. H. (1984). Teacher efficacy: A construct validation. Journal of Educational Psychology, 76(4), 569-582.http://dx.doi.org/10.1037/0022-0663.76.4.569

Guskey, T. (1988). Teacher efficacy, self-concept, and attitudes towards theimplementation of Instructional innovation. Teaching and Teacher Education, 4(1), 63-69. http://dx.doi.org/10.1016/0742-051X(88)90025-X

Hall, B., Hines, C., Bacon, T., \& Koulianos, G. (1992).Attributions that teachers hold to account for student success and failure and their relationship to teaching level and teacher efficacy beliefs. Paper presented at the annual meeting of the American Educational Research Association, San Francisco.

Hoy, W., \& Woolfolk, A. (1990). Socialization of Student Teachers. AmericanEducational Research Journal, 27(2), 279-300.http://dx.doi.org/10.3102/00028312027002279

Institute of Education Sciences. (2008). Dropout prevention: IES practice guide. Washington, DC: U.S. Department of Education.

Klassen, R. M., Tze, V. M. C., Betts, S. M., \& Gordon, K. A. (2011). Teacher efficacy research 1998-2009: Signs of progress or unfulfilled promise? Educational Psychology Review, 23, 21-43.http://dx.doi.org/10.1007/s10648-010-9141-8

Knesting, K. (2008). Students at risk for school dropout: Supporting their persistence. Preventing School Failure: Alternative Education for Children and Youth, 52(4), 3-10. http://dx.doi.org/10.3200/PSFL.52.4.3-10

Knesting, K., \& Waldron, N. (2006). Willing to play the game: How at-risk students persist in school. Psychology in the Schools, 43(5), 599-611. http://dx.doi.org/10.1002/pits.20174

Knesting-Lund, K., Reese, D., \& Boody, R. (2013). Teachers' perceptions of high school dropout and their role in dropout prevention: An initial investigation. Journal of Studies in Education, 3(4), 57-71. http://dx.doi.org/10.5296/jse.v3i4.4281

Kortering, L.J., \&Braziel, P.M. (1999). School dropout from the perspective of former students: Implications for secondary special education programs. Remedial and Special Education, 20, 78-83.http://dx.doi.org/10.1177/074193259902000203

Lehr, C.A., Hansen, A., Sinclair, M.F., \& Christenson, S.L. (2003). Moving beyond dropout towards school completion: An integrative review of data-based interventions. School Psychology Review, 32(3), 342-364.

Mac Iver, M. A. (2011). The challenge of improving urban high school graduation outcomes: Findings from a randomized study of dropout prevention efforts. Journal of Education for Student's Placed at Risk, 16, 167-184. http://dx.doi.org/10.1080/10824669.2011.584497

Midgley, C., Feldlaufer, H., \& Eccles, J. (1989). Change inteacher efficacy and student selfand task-related beliefs inmathematics during the transition to junior high school.Journal of Educational Psychology, 81, 247-258.http://dx.doi.org/10.1037/0022-0663.81.2.247 


\section{Macrothink}

Ross, J. A. (1992). Teacher efficacy and the effect of coachingon student achievement. Canadian Journal of Education, 17(1), 51-65.http://dx.doi.org/10.2307/1495395

Shidler, L. (2009). The impact of time spent coaching for teacher efficacy on student achievement. Early Childhood Education Journal, 36(5), 453-460.http://dx.doi.org/10.1007/s10643-008-0298-4

Tschannen-Moran, M., \& Woolfolk Hoy, A. (2001). Teacher efficacy: Capturing and elusive construct. Teaching and Teacher Education, 783-805.http://dx.doi.org/10.1016/S0742-051X(01)00036-1

U.S. Department of Education, Institute of Education Sciences. (2009). What Works Clearinghouse: Dropout prevention.Retrieved April 3, 2015 from http://ies.ed.gov/ncee/wwc/ Woolfolk, A., Rosoff, B., \& Hoy, W. (1990). Teachers' sense of efficacy and their beliefs about managing students. Teaching and Teacher Education, 6(2), 137-148.http://dx.doi.org/10.1016/0742-051X(90)90031-Y 